\title{
THE VISUALIZATION OF THE SPATIALITY OF AIRBNB IN BUDAPEST USING 3-BAND RASTER REPRESENTATION
}

\author{
Gábor DUDÁs ${ }^{1}$, Lajos BoRos ${ }^{2}$, Tamás KoVALCSIK², Balázs KoVALCSIK ${ }^{3}$
}

DOI: 10.21163/GT_2017.121.03

\begin{abstract}
:
Due to the development of ICT technologies the so-called sharing economy has spread all over the world, gaining significant market share in certain sectors. One of the well-known and debated manifestations of sharing economy is Airbnb, which is an online platform for accommodation provision. Airbnb has wide-spreading effects on rental and real estate markets, thus it is important to analyse the uneven spatial effects of the phenomenon. This paper aims to map and analyse the intra-urban spatial pattern of Airbnb using three indicators: prices, distance from centre, and attractiveness of the area. The case study area is Budapest, Hungary. Collecting data from various sources we compiled 3-band raster maps to present the significance of the selected indicators. The maps reveal the hotspots of Airbnb within the city and the effects of distance and attractiveness on Airbnb prices.
\end{abstract}

Key-words: Airbnb, GIS, Peer-to-peer accommodation, Budapest, Sharing economy.

\section{INTRODUCTION}

In recent years, the development of digital technologies and the diffusion of ICT worldwide alongside with the growth of Web 2.0 have facilitated and enabled the emergence of peer-to-peer based online platforms that promote user-generated content, sharing, and collaboration (Hamari et al, 2015; Kaplan \& Haenlein, 2010). These platforms and marketplaces are byproducts of a larger economic-technological phenomenon called the sharing economy (Hamari et al, 2015; Pizam, 2014).

The phenomenon itself is not new, but the Internet is accelerating its proliferation into everyday life and its recent impact on various industries is paramount (Olson \& Kemp, 2015). However, it is extremely challenging to offer a definition of what is the sharing economy and which platforms are included in, as platforms position themselves as part of the sharing economy (Oskam \& Boswijk, 2016) to gain advantage of the positive symbolic meaning of the concept. So, usually "self-definition of the platforms and the press defines who is in and who is out" (Schor, 2014, p. 2), but for sharing economy definitions see studies of Botsman (2015), Frenken et al (2015), and Oskam \& Boswijk (2016).

According to the PricewaterhouseCoopers research conducted in 2014, the five main sharing economy sectors (peer-to-peer lending and crowdfunding, online staffing, peer-topeer accommodation, car sharing, music and video sharing) in 2013 generated $\$ 15 \mathrm{bn}$ in global revenues but it is expected that these five sectors will generate $\$ 335 \mathrm{bn}$ in 2025 (PWC, 2014).

\footnotetext{
${ }^{l}$ Institute for Regional Studies, Hungarian Academy of Sciences, 5600 Békéscsaba, Hungary, dudasgabor5@gmail.com;

${ }^{2}$ University of Szeged, Department of Economic and Social Geography, 6722 Szeged, Hungary, borosl@geo.u-szeged.hu; mrkovalcsik@gmail.com

${ }^{3}$ University of Szeged, Department of Foundations of Computer Science, 6725 Szeged, Hungary, kobalaz@hotmail.com.
} 
Peer-to-peer (P2P) marketplaces associated with sharing economy operate particularly within the field of travel and tourism (Ert et al, 2016). In P2P marketplaces consumers transact directly with sellers and the whole process is maintained by a third party throughout an Internet platform (Ert et al, 2016; Pizam, 2014). However, the most popular P2P rental site is Airbnb (Gutiérrez et al, 2016; Pizam, 2014) a travel accommodation provider that describes itself as a "trusted community marketplace for people to list, discover, and book unique accommodations around the world" (Airbnb, 2016).

Since its foundation, Airbnb has grown extremely rapidly and now surpasses the major hotel chains in accommodation offered and market valuation (Guttentag, 2015; Oskam, 2016; Oskam \& Boswijk, 2016). Airbnb is present in more than 34000 cities and 191 countries, has more than 2 million global listings (Airbnb, 2016) and was valuated more than $\$ 24$ billion in 2015 and the company's revenue is expected to grow to $\$ 10$ billion until 2020 (Winkler \& MacMillan, 2015). As the rapid rise of Airbnb is still too recent, academic literature could not reflect thoroughly, although Airbnb is the best-documented case in P2P accommodation (Oskam \& Boswijk, 2016).

Relatively few empirical papers have yet studied Airbnb and these focus on some key issues such as trust or the reliability of online reviews (Ert et al, 2016; Ikkala \& Lampinen, 2014; Guttentag, 2015; Zervas et al, 2015), address legal issues surrounding Airbnb (Guttentag, 2015; Kaplan \& Nadler, 2015; McNamara, 2015), or there are studies quantifying the impact of Airbnb on the hotel industry (Choi et al, 2015; Zervas et al, 2016). However, there is a rising interest in the spatial distribution of hotels and Airbnb listings (Gutiérrez et al, 2016; Quattrone et al, 2016) within major cities to locate those parts of the city, which have seen the greatest pressure from tourism or "touristification" and its negative impacts on cities and residents diagnosed in a few studies (Blickhan et al, 2014; Oskam \& Boswijk, 2016).

Based on the previous paragraphs we think it is important to investigate the spatiality of Airbnb more deeply but none in a regular way using traditional mapping techniques. Accordingly, the purpose of the study was to create a map and mapping method that visualizes the spatiality of Airbnb using a 3-band raster image visualization taking into consideration different geographical indicators. So the central question of the paper is how the different geographical factors influence Airbnb spatiality in Budapest?

In the first half of the study, we developed a database for a large number of Airbnb listings that included data on price, distance, and point of interest data about tourist attractions and catering units in Budapest. In the second part, this data were mapped using Geographic Information System (GIS)-based mapping techniques. The results were 3-band raster layer maps which offer a visual representation of the spatiality of Airbnb in Budapest from a special point of view.

\section{METHODS}

\subsection{Applied data and the data mining method}

We started our study with the compilation of our database including the necessary data for the mapping of the spatiality of Airbnb. In order to create a 3-band raster layer, we selected three indicators: Airbnb prices, Distance (the distance of the Airbnb location to the city centre), and Attractiveness (attractiveness based on the location of points of interests). 
The first step was to collect data about Airbnb listings in Budapest and their prices. The examination of short-term rentals in the sharing economy sector is very difficult due to the deficiencies of official databases and as Airbnb operates mostly in the illegal and semiillegal sector (Guttentag, 2015). In the absence of appropriate databases, we had to perform our own data collection based on researches (Dudás et al, 2016a; Dudás et al, 2016b; Edelman \& Luca, 2014; Law et al, 2011; Zervas et al, 2016) facing similar problems. Due to our limited resources and constraints of the data source page (www.airbnb.com) we performed one manual query to obtain the necessary data. It should be noted that this paper mostly brings methodology, but by the interpretation of the results it should be taken into account that increasing the volume of the data query may result in different spatial pattern.

The query was on 1 June 2016 for checking in on 19 August 2016 (Friday) and checking out on 20 August 2016 (Saturday). The data collection concerned Airbnb listings in Budapest at the given time and contained the accommodation prices for one person for a one night stay. The data source for the second and the third indicator was the website www.geofabrik.de from which OpenStreetMap data was collected including the road network of Budapest and Points of Interest (POI) data of the Hungarian capital.

\subsection{Visualization process of the 3 raster layers}

Our study is based on a mapping method, which is decisively utilized in physical geography (Aghayev \& Rustamov, 2015; Szatmári et al, 2016), but there were attempts to model internal structure of Hungarian towns (Gyenizse et al, 2016). In our study, 3 different indicators will be represented on a single map at the same time using GIS. In order to map all the three indicators (Airbnb price, Distance, Attractiveness), we needed to transform these indexes into raster patterns and these three raster grids were then visualized using RGB false colour schemes in the selected study area (Budapest).

The first indicator was the Airbnb price in Budapest. The rasterization of this layer was made utilizing the shape file containing the positions (latitude and longitude coordinates) of the Airbnb listings and other attribute data. The technical background for this process was provided by ArcGIS 10.2. In this case, we used the Spatial Analyst tools/Interpolation/Topo to Raster tool to make the rasterization. This tool is primarily "designed for the creation of hydrologically correct digital elevation models (DEMs)" (ESRI, 2017), but we altered the input data to create such a surface model where the hilltops (local maximums) and few sinks (local minimums) represent Airbnb prices and their distribution in space. The result was a single-band raster image with a resolution of 100 meters, which was chosen because the collected data has 100 meter accuracy. Then, using the Spatial Analyst tools/Extraction/Extract by Mask tool we made a masking on our image in order to the pixels in the raster would only cover the administrative area of Budapest (Figure 1.a).

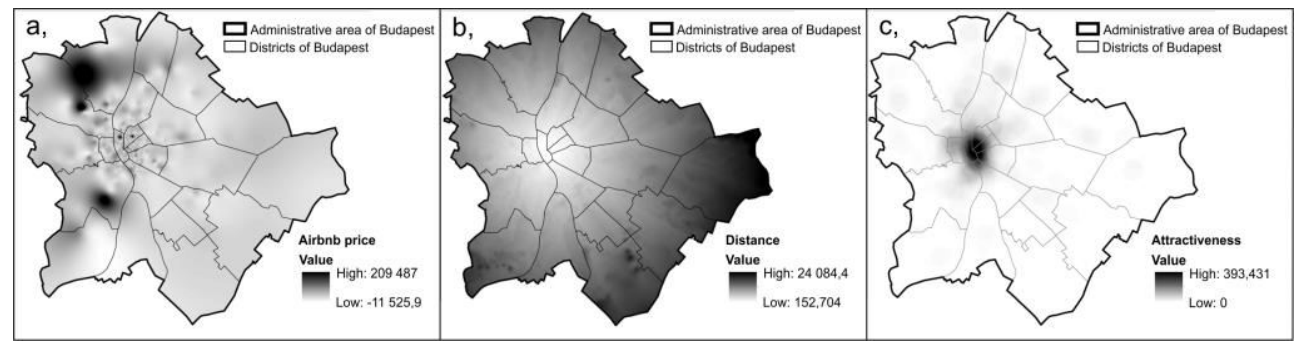

Fig. 1 Raster layers of the 3 indicators (edited by the authors). 
The second indicator (Distance) represents the Manhattan distance between Airbnb locations and the centre of Budapest. We selected the Deák Ferenc square (Deák Ferenc tér) as the centre point of Budapest, as this place is very popular among tourists and it is approximately geographically located in the centre of the city. Furthermore, the square is one of the most important public transport hubs in the city. To determine these distances, we used the free vector dataset of OpenStreetMap including the road network of Budapest. At the first step, this database was limited to the roads which could be used by car. Then, the data was transformed into a graph using the Imagine Logo software.

During the transformation, we determined the graphs' parameters such as the length of segments, maximum speed limit, obligatory direction, one-way or two-way street, etc. After finishing the controlled graph we calculated the shortest temporal and spatial path (Manhattan distance and time distance - the time needed to cover the Manhattan distance) between the Airbnb locations and the Deák square using the graph and our own pathfinding algorithm in a Dev-C++ software environment. The algorithm calculated in each case with ideal traffic conditions, however, we have to note that vehicles in the traffic adjust their speed to road conditions and to local density of the traffic (Boel \& Mihaylova, 2006), thus to simulate approximately real traffic conditions, 60 percent of the current speed limits were taken into account. In the last step, we applied the same procedure - as described in the previous paragraph - creating a surface where the low and high values represent the calculated distance values, furthermore, we paid attention to that the two layers pixel size and position would be the same (Figure 1b).

The third indicator represents attractiveness. Under this category, we understand hundreds of Point of Interests (POIs) of varying nature, from hospitals to restaurants and hotels. We considered POIs in this study based on the Points of Interest layer of the OpenStreetMap database that falls under one of the following categories: "eating and drinking", "attractions", "retail", "sports and entertainment". From this database, we selected the relevant categories which may attract the people who use the services offered by Airbnb. After that, using the Spatial Analyst tools/Density/Point Density tool, a surface model was created.

During this operation, we set the Radius value to 1000 meters in order to give every pixel in a 1000 meter radius of a poi a unit value, and create a buffer zone around the poi. Applying this operation to every poi we got such a surface which represents, that in a 1000 meter radius of the given point how much poi there is, in other words, how great its attractiveness is. Then, using the Spatial Analyst tools/Extraction/Extract by Mask tool this layer was also cut to cover only the administrative area of Budapest (Figure 1c).

Finally, the three layers were combined to one single raster image using the Data Management/Raster/Raster Processing/ Composite Bands tool. The results were 6 maps representing the same data but with different RGB-band combinations (Figure 2).

\subsection{Interpretation of the results}

According to the 3-band raster representation, we could generate 6 different maps representing the same data, but by changing the band combination we can emphasize diverse nexuses of the selected indicators. In a 123 band combination (Figure 2a) the red represents distance, and the darker is the red the closer is the centre point (Deák square) of the city. In this band order, the most stressful layer is Attractiveness and the greener is on the map the larger is the POI supply. This band combination mostly stresses the POI supply depending on distance, the Airbnb supply is less significant. 
In addition, this outlines that we may have chosen a proper centre point as the POI supply is the densest in the centre of the city. On the 132 band combination (Figure 2b) red still represents distance but the map highlights the density of Airbnb listings more clearly, and the greener is on the map the more expensive are the Airbnb accommodation prices. Moreover, the denser are the green islands the denser are the Airbnb listings. On the other hand, on the map the dark areas show the Airbnb gaps, where there is a lack of Airbnb supply, although these areas are close to the centre, however, the more these areas turn to blue the more attractive is the given area.

The 213 and 231 band combinations (Figure 2cd) on the whole shows similar picture than the first two band combinations, except that the 213 combination highlights the Airbnb supply of the outside areas more significantly. From the 6 maps, in our point of view, the 312 combination (Figure 2e) is the most informative. This represents the most interpretable way the distance from the centre (green) and the POI supply (blue), as well as the Airbnb density and the polarization of Airbnb prices. Accordingly, the orange and magenta islands represent the density and relative position of Airbnb listings and the smaller and the denser are these islands the denser is the Airbnb supply. Moreover, the redder are the pixels the more expensive are the Airbnb accommodations. The 321 band combination (Figure 2f) on the whole shows similar picture than the other band combinations but it highlights mainly the POI supply (green).

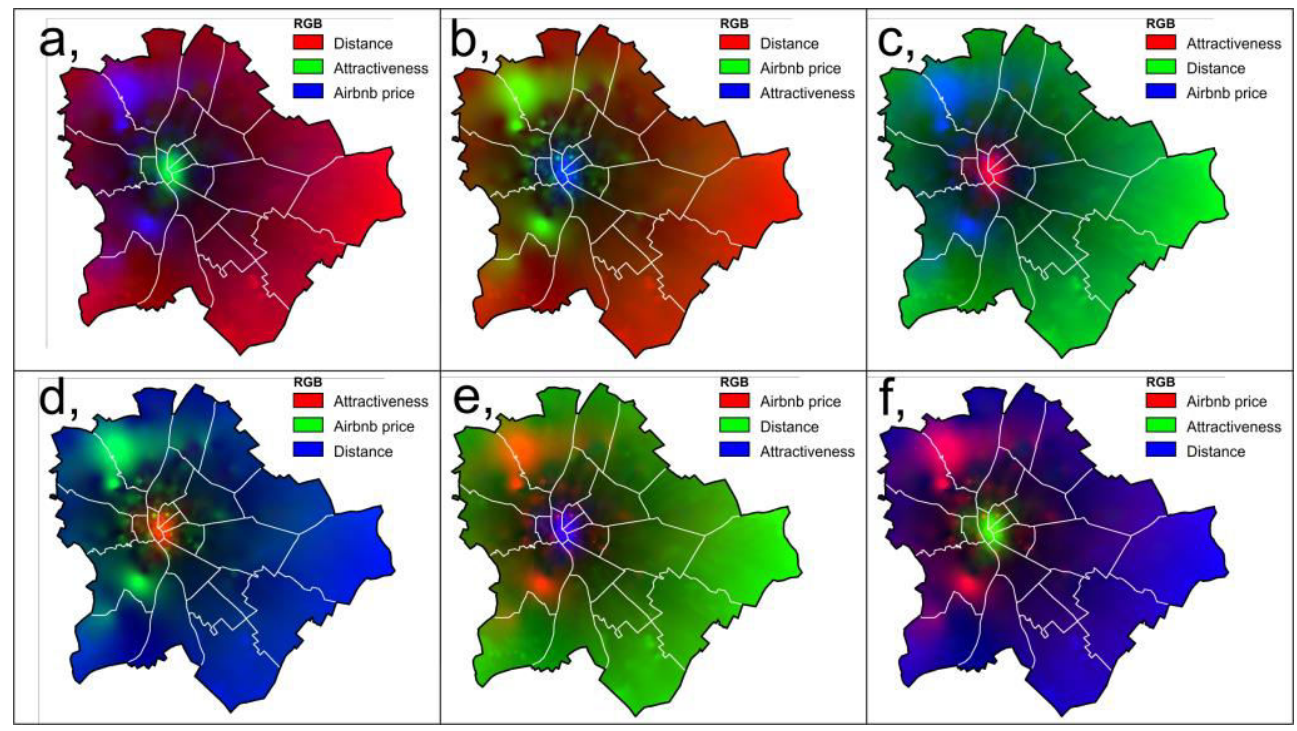

Fig. 2 3-band raster representation of the spatiality of Airbnb in Budapest (edited by the authors).

Overall, the maps show that correlation can be outlined between the POI supply and distance, which may also confirm our decision that we have chosen a correct centre point of Budapest as the main attractions concentrate around this point. The maps also highlight that the POI supply also correlates with the locations of Airbnb accommodations, showing that high density of Airbnb locations can be found in places which are popular places among tourists and offer a lot of facilities serving the needs of them. 
The results also emphasize that there is no significant correlation between the price and the location of the Airbnb accommodation in Budapest, but this could be an interesting research topic for the future to examine is it a Hungarian or rather a general phenomenon in cities of the globe, where Airbnb is present.

\section{CONCLUSIONS}

The research presents a method to map the spatiality of Airbnb, however, not in a regular way but by using additional indicators (distance, attractiveness) and a 3-band raster layer visualisation method. During the study, we created a database for a large number of Airbnb listings and developed a way to measure the distances of Airbnb locations from a central point. The main results of this work is a set of maps showing the density and price of Airbnb listings. This allows people to see a relative picture of Airbnb listings in relation to other indicators as distance and attractiveness. Although, it should be noted that the paper mostly brings methodology and we also emphasize too that to conduct a deeper and wider empirical analysis works on the input data are needed. The maps generated with our method can be useful information sources for planners and also for decision-makers as well.

Future research directions could be increasing the number of the layers by including additional indicators as for example location and room prices of Hotels or splitting the Airbnb prices and locations into 2 layers. We hope that our study will encourage further research on this topic and raise further interest among geographers and researchers from other disciplines.

\section{R E F E R E N C E S}

Aghayev, A. T. \& Rustamov, R. B. (2015) Remote Sensing and Geographic Information System/Geodatabase in River Flood Mapping. Journal of Surveying and Mapping Engineering, $3,1-11$.

Airbnb (2016) About us. [Online] Available from: https://www.airbnb.com/about/about-us [Accessed November 2016].

Blickhan, M., Bürk, T. \& Grube, N. (2014) Touristification in Berlin. sub|urban. Zeitschrift für kritische Stadtforschung, 2, 167-180.

Boel, R. \& Mihaylova, L. (2006) A compositional stochastic model for real time freeway traffic simulation. Transportation Research Part B: Methodological, 40, 319-334.

Botsman, R. (2015) Defining the Sharing Economy: What Is Collaborative Consumption-And What Isn't? [Online] Available from: https://www.fastcoexist.com/3046119/defining-the-sharingeconomy-what-is-collaborative-consumption-and-what-isnt [Accessed November 2016].

Choi, K-H., Jung, J., Ryu, S., Kim, S-D. \& Yoon, S-M. (2015) The relationship between Airbnb and the hotel revenue: in the case of Korea. Indian Journal of Science and Technology, 8, 1-8.

Dudás, G., Boros, L., Pál V. \& Pernyész P. (2016a) Analysis of the lowest airfares considering the different business models of airlines, the case of Budapest. Regional Statistics, 6, 119-138.

Dudás, G., Boros, L., Pál V. \& Pernyész P. (2016b) Mapping cost distance using air traffic data. Journal of Maps, 12, 695-700. 
Edelman, B. \& Luca, M. (2014) Digital Discrimination: The Case of Airbnb.com. Harvard Business School working Paper 14-054.

Ert, E., Fleischer, A. \& Magen, N. (2016) Trust and reputation in the sharing economy: The role of personal photos in Airbnb. Tourism Management, 55, 62-73.

ESRI ArcGIS Pro tool reference (2017) How Topo to Raster works. [Online] Available from http://pro.arcgis.com/en/pro-app/tool-reference/3d-analyst/how-topo-to-raster-works.htm [Accessed January 2017].

Frenken, K., Meelen, T., Arets, M. \& Glind, P. V. (2015) Smarter regulation for the sharing economy. theguardien, [Online] Available from https://www.theguardian.com/science/politicalscience/2015/may/20/smarter-regulation-for-the-sharing-economy [Accessed November 2016].

Gutiérrez, J., García-Palomares, J. C., Romanillos, G. \& Salas-Olmedo, M. H. (2016) Airbnb in touristic cities: comparing spatial patterns of hotels and peer-to-peer accommodations. ArXiv. [Online] Available from: https://arxiv.org/ftp/arxiv/papers/1606/1606.07138.pdf [Accessed November 2016].

Guttentag, D. (2015) Airbnb: disruptive innovation and the rise of an informal tourism accommodation sector. Current Issues in Tourism, 18, 1192-1217.

Gyenizse, P., Trócsányi, A., Pirisi, G., Bognár, Z. \& Czigány, Sz. (2016) A multi-factor model developed on residents' opinions for the classification of urban residential areas. Geografie, 121, $1-31$.

Hamari, J., Sjöklint, M. \& Ukkonen, A. (2016) The sharing economy: Why people participate in collaborative consumption. Journal of the Association for Information and Science and Technology, 67, 2047-2059.

Ikkala, T. \& Lampinen, A. (2014) Defining the price of hospitality: networked hospitality exchange via Airbnb. Proceedings of the companion publication of the $17^{\text {th }}$ ACM conference on Computer supported cooperative work \& social computing, 173-176.

Kaplan, A. M. \& Haenlein, M. (2010) Users of the world unite! The challenges and opportunities of Social Media. Business horizons, 53, 59-68.

Kaplan, R. A. \& Nadler, M. L. (2015) Airbnb: a case study in occupancy regulation and taxation. The University of Chicago Law Review Dialogue, 82, 103-105.

Law, R., Leung, R. \& Lee, H. A. (2011) Temporal Changes of Airfares Toward Fixed Departure Date. Journal of Travel and Tourism Marketing, 28, 615-628.

McNamara, B. (2015) Airbnb: A not-so-safe resting place. Colorado Technology Law Journal, 13, 149-169.

Olson, M. J. \& Kemp, S. J. (2015) Sharing Economy - An In-Depth Look At Its Evolution \& Trajectories Across Industries. PiperJaffay. Investment Research. [Online] Available from: http://collaborativeeconomy.com/wp/wp-content/uploads/2015/04/Sharing-Economy-An-In-

Depth-Look-At-Its-Evolution-and-Trajectory-Across-Industries-.pdf [Accessed November 2016].

Oskam, J. (2016) Airbnb or "Networked Hospitality Businesses": Between Innovation and Commercialization. A Research Agenda. The proceedings of HONG KONG 216: $2^{\text {nd }}$ Global Tourism \& Hospitality Conference and $15^{\text {th }}$ Asia Pacific Forum for Graduate Students Research In Tourism Vol. 1.

Oskam, J. \& Boswijk, A. (2016) Airbnb: the future of networked hospitality businesses. Journal of Tourism Futures, 2, 22-42.

Pizam, A. (2014) Peer-to-peer travel: Blessing or blight? International Journal of Hospitality Management, 38, 118-119. 
PWC - PricewaterhouseCoopers (2014). The sharing economy - sizing the revenue opportunity. [Online] Available from: http://www.pwc.co.uk/issues/megatrends/collisions/sharingeconomy/the-sharing-economysizing-the-revenue-opportunity.html [Accessed November 2016].

Quattrone, G., Proserpio, D., Quercia, D., Capra, L. \& Musolesi, M. (2016) Who benefits from the "sharing" economy of Airbnb? Proceedings of the $25^{\text {th }}$ International Conference on World Wide Web, 1385-1394.

Schor, J. (2014) Debating the sharing economy. Great Transition Initiative - Toward a Transformative Vision and Practice. [Online] Available from: http://www.greattransition.org/publication/debating-the-sharing-economy [Accessed November 2016].

Szatmári, J., Tobak, Z. \& Novák Zs. (2016) Environmental monitoring supported by aerial photography - A case study of the burnt down bugac juniper forest, Hungary. Journal of Environmental Geography, 9, 31-38.

Winkler, R. \& MacMillan, D. (2015) The Secret Math of Airbnb's \$24 Billion Valuation. The Wall Street Journal. [Online] Available from: https://www.wsj.com/articles/the-secret-math-ofairbnbs-24-billion-valuation-1434568517 [Accessed November 2016].

Zervas, G., Proserpio, D. \& Byers, J. (2015). A first look at online reputation on Airbnb, where every stay is above average (January 28, 2015). [Online] Available from: http://papers.ssrn.com/sol3/papers.cfm?abstract_id=2554500 [Accessed November 2016].

Zervas, G., Proserpio, D. \& Byers, J. (2016). The Rise of the Sharing Economy: Estimating the Impact of Airbnb on the Hotel Industry. Boston U. School of Management Research Paper No. 2013-16. 